\title{
Determinants of choosing a career in family medicine
}

\author{
Ian Scott MD MSc, Margot Gowans BSc, Bruce Wright MD, Fraser Brenneis MD, Sandra Banner, Jim Boone
}

\begin{abstract}
Background: Student choice is an important determinant of the distribution of specialties of practising physicians in many countries. Understanding characteristics at entry into medical school that are associated with the choice of residency in family medicine can assist medical schools in admitting an appropriate mix of students to serve the health care needs of their regions.
\end{abstract}

Methods: From 2002 to 2004, we collected data from students in 15 classes at 8 of 16 Canadian medical schools at entry. Surveys included questions on career choice, attitudes to practice and socio-demographic characteristics. We followed students prospectively with these data linked to their residency choice. We used multiple logistic regression analysis to identify entry characteristics that predicted a student's ultimate career choice in family medicine.
Results: Of 1941 eligible students in the participating classes, 1542 (79.4\%) contributed data to the final analyses. The following 11 entry variables predicted whether a student named family medicine as his or her top residency choice: being older, being engaged or in a long-term relationship, not having parents with postgraduate university education nor having family or close friends practicing medicine, having undertaken voluntary work in a developing nation, not volunteering with elderly people, desire for varied scope of practice, a societal orientation, a lower interest in research, desire for short postgraduate training, and lower preference for medical versus social problems.

Interpretation: Demographic and attitudinal characteristics at entry into medical school predicted whether students chose a career in family medicine.
Competing interests:

Sandra Banner is executive director and chief executive officer of the Canadian Resident Matching Service. Jim Boone is general manager and chief operating officer of the Canadian Resident Matching Service. No competing interests declared by Ian Scott, Margot Gowans, Bruce Wright and Fraser Brenneis.

This article has been peer reviewed.

Correspondence to:

Dr. Ian Scott,

ianscott@interchange.ubc.ca

CMAJ 2011. DOI:10.1503 /cmaj.091805
$\mathrm{T}$ he number of physicians per capita in both Canada and the United States has declined, and this decline is expected to continue. Canada has already experienced a drop of $5.1 \%$ in the physician-to-population ratio from a peak in 2000 , and in the United States a shortage of up to 200000 physicians, or $20 \%$ of the needed workforce, is predicted to occur by $2025.1,2$ Combined with a growing elderly population and decreasing physicianhours, ${ }^{3,4}$ this reduction in the physician-topopulation ratio is expected to have implications for the health care systems of both countries. Therefore, health resource planners likely will be looking to expand the role of primary care, and of family medicine in particular. ${ }^{5-8}$ To support such an expansion, a commensurate increase in the numbers of domestically trained family physicians will be required. But with as few as 25\% (in 2003) ( $^{9}$ of Canadian medical graduates choosing family medicine as their top career choice in the residency match, it is unlikely the health care system will be able to supply adequate numbers of primary care physicians.

In most countries, the number and the distribution of specialties of physicians are determined by numerous factors, including government policies, training opportunities, immigration and emigration of providers, sex and age distribution of providers, and remuneration incentives and disincentives. ${ }^{10-17}$ In many medical systems, the career interests of students also have a substantial steering effect on the distribution and number of available physicians. ${ }^{18,19}$

The purpose of this study was to follow a large cohort of Canadian medical students from school entry through exit to examine how their career aspirations changed over time and to identify, using multiple logistic regression analysis, the variables at entry into medical school that predict a career choice of family medicine at graduation.

\section{Methods}

\section{Study population}

From 2002 through 2004, we distributed a 41item survey to first-year students in 15 classes at 8 out of a possible 16 Canadian medical schools within two weeks of commencement of their medical studies. The study included three entry classes from the University of British Columbia (2002-2004); two each from the University of Calgary (2003-2004), the University of Toronto 
(2003-2004), McMaster University (20032004), Queen's University (2003-2004) and the University of Western Ontario (2003-2004); and one each from the University of Alberta (2002) and the University of Ottawa (2003). This subset of Canadian medical schools was chosen by convenience sampling. We were able to sample half of the medical schools in Canada at that time because of personal contacts and interest from these schools in participating in this study. Different sampling periods occurred at different schools because some schools that started this research dropped out after one or more years. Schools that dropped out or did not participate in every year of the study were those not able to distribute surveys face-to-face during the first two weeks of classes.

\section{Questionnaire}

Survey questions were selected based on an extensive literature review and consultation process. Verification of survey comprehensiveness and appropriateness, and subsequent pilot- ing, were undertaken before commencement of the study; the survey tool was modified as appropriate. ${ }^{20}$ The survey asked students to consider eight career options, which were emergency medicine, family medicine, internal medicine, obstetrics and gynecology, pediatrics, psychiatry, surgery and "other" (a write-in choice). Students were asked to indicate which they would consider as a possible career and to rank their top three career choices. Using a 5-point Likert scale, ranging from 1 (no influence) to 5 (major influence), students were then asked to indicate the extent to which their career interests were influenced by the 27 different items listed in Table 1. Twenty-five of these items duplicated those we reported in $2004 ;{ }^{20}$ an additional two items have since been identified and added to the survey tool. The survey also collected sociodemographic data.

Data collected from students at entry to medical school were linked anonymously with their top career choice as submitted to the Canadian Resident Matching Service (CaRMS) and

Table 1: Factors derived from analysis of survey responses related to underlying attitudinal variables

\begin{tabular}{|c|c|c|c|c|c|}
\hline Factor & Underlying attitudinal variable & Loading* & Mean (SD) & Eigenvalue $†$ & Cronbach $\alpha \neq$ \\
\hline \multirow[t]{5}{*}{ 1. Medical lifestyle } & Flexibility outside of medicine & 0.802 & $3.65(1.11)$ & \multirow{5}{*}{3.20} & \multirow{5}{*}{0.83} \\
\hline & Acceptable hours of practice & 0.784 & $3.41(1.25)$ & & \\
\hline & Flexibility inside of medicine & 0.756 & $3.84(1.03)$ & & \\
\hline & Acceptable on-call schedule & 0.742 & $3.34(1.21)$ & & \\
\hline & Keeping options open & 0.681 & $3.58(1.09)$ & & \\
\hline \multirow[t]{4}{*}{ 2. Societal orientation } & Health promotion important & 0.692 & $3.63(1.17)$ & \multirow{4}{*}{2.79} & \multirow{4}{*}{0.73} \\
\hline & Long-term relationship with patients & 0.679 & $3.31(1.23)$ & & \\
\hline & Focus on patients in the community & 0.681 & $3.32(1.23)$ & & \\
\hline & Social commitment & 0.637 & $3.29(1.26)$ & & \\
\hline \multirow[t]{4}{*}{ 3. Prestige } & High income potential & 0.752 & $2.16(1.17)$ & \multirow{4}{*}{2.67} & \multirow{4}{*}{0.72} \\
\hline & Adequate income to eliminate debt & 0.708 & $2.14(1.31)$ & & \\
\hline & Status among colleagues & 0.694 & $1.91(1.05)$ & & \\
\hline & Stable or secure future & 0.636 & $1.79(1.10)$ & & \\
\hline \multirow[t]{3}{*}{ 4. Hospital orientation } & Focus on urgent care & 0.758 & $2.95(1.25)$ & \multirow{3}{*}{2.31} & \multirow{3}{*}{0.68} \\
\hline & Focus on in-hospital care & 0.726 & $2.88(1.29)$ & & \\
\hline & $\begin{array}{l}\text { Results of interventions immediately } \\
\text { available }\end{array}$ & 0.679 & $3.08(1.23)$ & & \\
\hline \multirow[t]{2}{*}{ 5. Scope of practice } & Wide variety of patient problems & -0.701 & $3.61(1.89)$ & \multirow{2}{*}{1.74} & \multirow{2}{*}{$-0.50 \S$} \\
\hline & Narrow variety of patient problems & 0.820 & $2.74(1.27)$ & & \\
\hline \multirow[t]{2}{*}{ 6. Role model } & Meaningful past experience with physician & 0.847 & $2.96(1.45)$ & \multirow{2}{*}{1.71} & \multirow{2}{*}{$0.59 \S$} \\
\hline & Emulate a physician & 0.856 & $2.51(1.43)$ & & \\
\hline $\begin{array}{l}\text { Items not loading into } \\
\text { any factor }\end{array}$ & \multicolumn{5}{|c|}{$\begin{array}{l}\text { Good match to this career, interesting patient population, focus on non-urgent care, dislike for } \\
\text { uncertainty, prefer medical to social problems, research interest, short postgraduate training }\end{array}$} \\
\hline \multicolumn{6}{|c|}{$\begin{array}{l}\text { Note: } S D=\text { standard deviation. } \\
\text { *Loading represents the correlation between the item and overall factor. } \\
\text { tEigenvalue measures the variance of the factor. } \\
\text { ¥Chronbach } \alpha \text { measures internal consistency of test scores, with a high } \alpha \text { indicating an underlying construct. } \\
\text { §Factors } 5 \text { and } 6 \text { have only two component items; the } r \text { value is given as } r=\alpha \text { under these conditions. }\end{array}$} \\
\hline
\end{tabular}


matched by an independent third party, the Canadian Post-MD Education Registry (CAPER). CaRMS is a not-for-profit organization that provides an electronic application and residency matching service to all medical students entering into postgraduate medical training positions throughout Canada. ${ }^{18}$ CAPER represents a partnership of professional medical organizations and federal, provincial and territorial governments. ${ }^{21}$

\section{Statistical analysis}

We profiled student career preferences at both entry to and exit from medical school using descriptive statistics. Demographic associations with career interest were identified using $t$ tests for continuous variables and $\chi^{2}$ tests for categorical variables. A principal-components factor analysis was performed to condense the 27 attitudinal career influences into a smaller number of coherent factors. Items that showed a minimum factor loading of 0.6 and factors with an eigenvalue greater than 1 were retained. We used $t$ tests to identify differences in the resulting factors according to career interest.

Logistic regression was used to identify both the predictors of a career in family medicine at exit from medical school as well as predictors of a switch in career interests toward or away from family medicine during medical school. Variables identified by univariable analyses as being significantly associated with a career choice in family medicine at medical school exit were entered into stepwise logistic regression analyses, with choosing family medicine or switching career interests as dichotomous outcome variables. We considered $p$ values less than or equal to 0.05 to be significant.

This research was approved by the research ethics board of the University of British Columbia.

\section{Results}

There were 2070 students in the 15 participating classes, with 1542 of these students contributing to the final analysis (Figure 1). The career choices of students who responded to our survey did not differ significantly from those of the national cohort of students graduating from medical school over the same time frame $(p=0.90)$ (Table 2$)$.

Of the 481 students who named family medicine as their top choice of career on exit from medical school, 250 (52.0\%) had named family medicine as their preferred career choice on entry, and $411(85.4 \%)$ had named it as one of their top three choices on entry to medical school. By contrast, of the 1061 students who named a career other than family medicine as their top choice on exit from medical school, 165
(15.6\%) had named family medicine as their preferred option on entry, and 549 (51.7\%) had included family medicine as one of their top three choices on entry.

When factor analysis was carried out on the 27 attitudinal variables influencing career choice, six factors containing 20 of these variables were identified. The factors were named by the authors according to their component variables (Table 1). Four of the factors (medical lifestyle, societal orientation, varied scope of practice and hospital orientation) comprised the same underlying variables as identified by earlier analyses..$^{20}$ Compared with earlier analyses, the fifth factor (prestige) contained one additional variable, which was "stable or secure

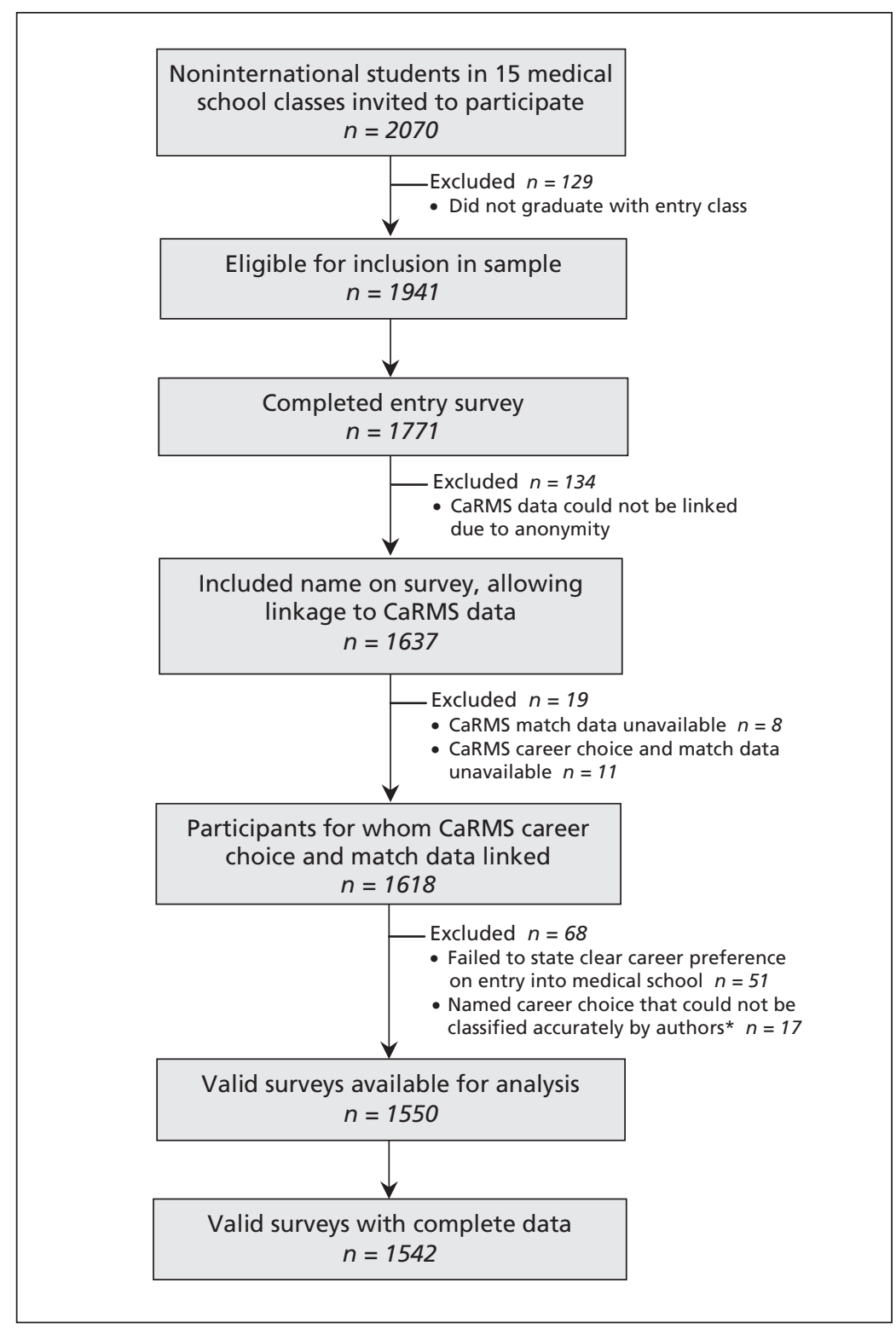

Figure 1: Recruitment and follow-up of cohort. *For example, sports medicine could be classified as either family medicine or orthopedics. CaRMS = Canadian Resident Matching Service. 
future." ${ }^{20}$ A sixth factor, "role model," was newly identified in this study. Whereas positive correlations existed between a career choice in family medicine and the factors of medical lifestyle $(r=0.11)$, societal orientation $(r=0.25)$ and varied scope of practice $(r=0.26)$, negative correlations existed between a career choice in family medicine and prestige $(r=-0.11)$ and hospital orientation $(r=-0.18)$. The factor "role model" was not associated with career choice. Together the six factors collectively explained $53.4 \%$ of variance in the responses. Seven items failed to load on any of the factors and were included as separate variables in the subsequent analyses.

Univariable analysis found five of these six factors, as well as several demographic variables, to have significant associations with career choice on exit from medical school (Table 3).

Logistic regression analysis that did not include stated career interest in family medicine on entry into medical school identified 11 variables that predicted a career choice in family medicine on exit (Table 4). When a student's stated career interest in family medicine on entry into medical school was included in the model, this variable was the strongest predictor of a career choice in family medicine on exit. In this model, two items that were significant predictors in the model that omitted career choice on entry (a higher degree of social orientation and a desire for short postgraduate training) were no longer independent predictors of a career choice in family medicine on exit (Table 4).

Variables predicting a switch in career choice toward family medicine between entry into and exit from medical school are shown in Table 5.

\begin{tabular}{|lrrrr|}
$\begin{array}{l}\text { Table 2: Career choices of survey sample compared with those in } \\
\text { Canadian Resident Matching Service (CaRMS) national dataset (match } \\
\text { years 2006-2007) }\end{array}$ & $\begin{array}{c}\text { Students in study, } \\
\text { no. (\%) }\end{array}$ & $\begin{array}{c}\text { CaRMS dataset, } \\
\text { no. (\%) }\end{array}$ \\
\hline Specialty & 481 & $(31.2)$ & 1852 & $(30.5)$ \\
\hline Family medicine & 309 & $(20.0)$ & 1223 & $(20.1)$ \\
\hline Internal medicine & 285 & $(18.5)$ & 1089 & $(17.9)$ \\
\hline Surgery & 91 & $(5.9)$ & 373 & $(6.1)$ \\
\hline Pediatrics & 82 & $(5.3)$ & 315 & $(5.2)$ \\
\hline Psychiatry & 75 & $(4.9)$ & 286 & $(4.7)$ \\
\hline Obstetrics and gynecology & 47 & $(3.0)$ & 177 & $(2.9)$ \\
\hline Emergency medicine & 172 & $(11.2)$ & 755 & $(12.4)$ \\
\hline Other* & 1542 & $(100.0)$ & 6070 & $(100.0)$ \\
\hline Total & & & & \\
\hline *Comprises radiology, community medicine, laboratory medicine and anesthesia. & \\
\hline
\end{tabular}

Students who switched to family medicine at exit from medical school $(n=231)$ did so predominantly from internal medicine $(n=64$, $27.7 \%)$ and pediatrics $(n=60,26.0 \%)$.

Variables predicting a switch in career choice away from family medicine between entry into and exit from medical school are shown in Table 6. Students who switched from family medicine on entry into medical school $(n=165)$ were most likely to switch into internal medicine $(n=55,33.3 \%)$ on exit.

\section{Interpretation}

If primary care is going to be central to future reforms and renewals of heath care systems, ${ }^{3,6,8,9}$ countries embarking on these renewals will need sufficient numbers of family physicians. Given that student career choice is an important determinant of human resources in health care, an understanding of the variables present on entry into medical school that are associated with a subsequent choice of career in family medicine could allow for preferential selection of students who are likely to meet the health needs of the population.

In our study, having family medicine as a career choice on entry was the most important predictor of a student's ultimate career choice. There may be value in a determination by admissions committees of a student's early commitment to family medicine if they wish to increase the number of family physicians that their schools produce. A downside of asking this question at admission is that such a scenario can be "gamed" by students once applicants become aware of the desired answers to this question. By removing career interest on medical school entry from our model, we were able to retain nearly the same accuracy (only $2.6 \%$ lower) with 11 significant predictive items. Whereas demographic factors such as age and relationship status would be considered inappropriate to ask a student in many jurisdictions, a number of the other items, particularly the attitudinal items, could be used by admissions committees to identify students more likely to choose a career in family medicine.

In our study, interest in family medicine increased during the course of medical school, with switchers to family medicine accounting for $48.0 \%(n=231)$ of the group of students applying for a family medicine residency. Students who switched to family medicine from a specialty career during medical school showed several differences from those who maintained an interest in a career not in family medicine, and shared more than half of the variables we evaluated with those who stayed with a career 
in family medicine. These findings support the notion of an underlying family medicine construct carried by entering medical students. Students who do not have family medicine as their top career choice but who have these attributes may be targeted by educators who wish to encourage students to switch to a career in family medicine. Students who switched from family medicine to a specialty career shared attributes with those students who stayed with a specialty career throughout medical school.

As with other studies, we found a stated preference for family medicine at medical school entry to be a strong predictor of an exit career choice in family medicine, ${ }^{14,22}$ but unlike other studies, we did not find this interest in primary care to wane after medical school admission. ${ }^{23-25}$

Some of the predictive variables we identified in our study have been described elsewhere, though the reported effects sometimes conflict. These include age, ${ }^{13}$ marital status,${ }^{13}$ having a societal orientation and volunteering in a developing country. ${ }^{14,26}$ Rural origin, which has been shown by others to be predictive, ${ }^{27,28}$ was not associated with a career choice of family medicine in our study; however, it was associated with a decreased likelihood of switching career interests away from family medicine during medical school. As in our study, scope of practice has been shown in some studies to draw stu-

Table 3: Associations between demographic and attitudinal variables and career choice of family medicine at exit from medical school

\begin{tabular}{|c|c|c|c|}
\hline Variable & $\begin{array}{l}\text { Family medicine } \\
\qquad n=481\end{array}$ & $\begin{array}{c}\text { Specialty medicine } \\
\qquad n=1061\end{array}$ & $p$ value \\
\hline \multicolumn{4}{|l|}{ Demographic characteristic } \\
\hline Sex, male, \% & 34.9 & 45.5 & $<0.001$ \\
\hline Relationship status, single \% & 61.5 & 75.2 & $<0.001$ \\
\hline Family or friends in family medicine, \% & 21.8 & 20.1 & 0.430 \\
\hline Family or friends in any field of medicine, $\%$ & 33.5 & 41.5 & 0.003 \\
\hline Hometown population $<50$ 000, \% & 28.1 & 18.6 & $<0.001$ \\
\hline Rural childhood, resided in rural area for $>50 \%$ of childhood, $\%$ & 28.3 & 18.9 & $<0.001$ \\
\hline \multicolumn{4}{|l|}{ Attitudinal factor, mean (SD)* } \\
\hline Factor 1: Medical lifestyle & $3.72(0.82)$ & $3.50(0.90)$ & $<0.001$ \\
\hline Factor 2: Societal orientation & $3.74(0.84)$ & $3.24(0.89)$ & $<0.001$ \\
\hline Factor 3: Prestige & $1.86(0.79)$ & $2.06(0.88)$ & $<0.001$ \\
\hline Factor 4: Hospital orientation & $2.72(0.90)$ & $3.09(0.99)$ & $<0.001$ \\
\hline Factor 5: Varied scope of practicet & $3.85(0.94)$ & $3.25(1.06)$ & $<0.001$ \\
\hline Factor 6: Role model & $2.69(1.23)$ & $2.76(1.30)$ & 0.278 \\
\hline \multicolumn{4}{|l|}{ Attitudinal items not loading into any factor, mean (SD) $\ddagger$} \\
\hline Good match to this career & $2.09(1.20)$ & $2.22(1.34)$ & 0.046 \\
\hline \multicolumn{4}{|c|}{$\begin{array}{l}\text { *Values shown for attitudinal factors } 1-4 \text { and } 6 \text { are the means of component item scores. } \\
\text { †Because of inverse association between the two component items of factor } 5 \text { (i.e., wide-to-narrow variety of patient problems), the item "narrow variety of } \\
\text { patient problems" was transposed before calculation of the mean, producing a factor that reflected a varied scope of practice. } \\
\text { ¥Values for attitudinal items were scored on a 5-point scale, with higher scores indicating a greater influence on career choice. }\end{array}$} \\
\hline
\end{tabular}


dents toward family medicine ${ }^{29}$ but others have shown it to lead students to reject family medicine. ${ }^{30}$ In contrast to other studies, ${ }^{13,14,31}$ the student's sex was not found to be a significant predictor in our model. This may be due to the increasing number of women in medical school.

Our study on career interest at exit from medical school built on a previous study ${ }^{20}$ that identified predictors of a student's career interest at medical school entry. We found that most variables were represented in both studies, given that they were derived from the same survey answers obtained from students on entry into medical school. Since each of these studies used a different outcome variable (i.e., career choice on entry into medical school versus career choice on exit), certain items not previously identified became important when looking at a student's ultimate career choice. Rela- tionships, volunteer work in developing nations and parental education endured as predictors throughout the process of medical education. Age, varied scope of practice and a strong societal orientation, while remaining predictive of a career interest in family medicine, were less important influences on final career choice than on entry choice, indicating that the experience of medical school may have lessened the influence of these items. A low interest in hospital care, interest in medical lifestyle and having completed high school in a smaller community were no longer significant predictors of career choice on exit from medical school.

\section{Limitations}

Although the survey underwent a thorough development and validation process, other important influences may have been overlooked.

Table 4: Multivariable logistic regression analysis of factors found to be significantly associated with a career choice in family medicine on exit from medical school

\begin{tabular}{|c|c|c|c|c|}
\hline Variable & $\begin{array}{l}\text { Students who } \\
\text { selected family } \\
\text { medicine as } \\
\text { residency choice }\end{array}$ & $\begin{array}{c}\text { Crude OR } \\
(95 \% \mathrm{Cl})\end{array}$ & $\begin{array}{l}\text { Adjusted OR, } \\
\text { excluding entry } \\
\text { career choice } \\
(95 \% \mathrm{Cl})\end{array}$ & $\begin{array}{l}\text { Adjusted OR, } \\
\text { including entry } \\
\text { career choice } \\
(95 \% \mathrm{Cl})\end{array}$ \\
\hline \multicolumn{5}{|l|}{ Entry career choice of family medicine, no. (\%) } \\
\hline No & $231(20.5)$ & $1.0 \dagger$ & - & $1.0+$ \\
\hline Yes & $250(60.2)$ & $5.88(4.60-7.50)$ & - & $2.37(1.68-3.34)$ \\
\hline Age, yr, mean (SD)* & $24.9(4.1)$ & $1.11(1.07-1.15)$ & $1.06(1.03-1.11)$ & $1.06(1.01-1.10)$ \\
\hline \multicolumn{5}{|l|}{ Relationship status, no. (\%) } \\
\hline Single & $296(27.1)$ & $1.0+$ & $1.0+$ & $1.0+$ \\
\hline Engaged or long-term & $185(41.3)$ & $1.90(1.51-2.39)$ & $1.42(1.08-1.87)$ & $1.46(1.10-1.93)$ \\
\hline \multicolumn{5}{|l|}{ Parental education, no. (\%) } \\
\hline$<$ postgraduate & $303(35.4)$ & $1.0 \dagger$ & $1.0+$ & $1.0+$ \\
\hline Postgraduate & $178(25.9)$ & $0.64(0.51-0.80)$ & $0.74(0.57-0.96)$ & $0.76(0.58-0.98)$ \\
\hline \multicolumn{5}{|l|}{ Relative or friend in medicine, no. (\%) } \\
\hline No & $320(34.0)$ & $1.0 \dagger$ & $1.0 \dagger$ & $1.0+$ \\
\hline Yes & $161(26.8)$ & $0.71(0.57-0.89)$ & $0.74(0.56-0.96)$ & $0.73(0.56-0.97)$ \\
\hline \multicolumn{5}{|l|}{ Volunteer with elderly people, no. (\%) } \\
\hline No & $273(33.6)$ & $1.0 \dagger$ & $1.0 \dagger$ & $1.0 \dagger$ \\
\hline Yes & $208(28.5)$ & $0.79(0.64-0.98)$ & $0.77(0.60-0.98)$ & $0.77(0.60-0.99)$ \\
\hline \multicolumn{5}{|l|}{ Volunteer in developing nation, no. (\%) } \\
\hline No & $348(28.4)$ & $1.0 \dagger$ & $1.0 \dagger$ & $1.0 \dagger$ \\
\hline Yes & $133(41.8)$ & $1.81(1.40-2.34)$ & $1.59(1.12-2.13)$ & $1.62(1.20-2.17)$ \\
\hline Factor 2: Societal orientation, mean (SD)* & $3.4(0.9)$ & $1.93(1.69-2.20)$ & $1.33(1.12-1.58)$ & $1.18(0.96-1.41)$ \\
\hline Factor 5: Varied scope of practice, mean (SD)* & $3.8(0.9)$ & $1.80(1.60-2.01)$ & $1.40(1.23-1.60)$ & $1.24(1.08-1.43)$ \\
\hline Item P: Prefer medical to social problems, mean (SD)* & $2.1(1.2)$ & $0.70(0.64-0.76)$ & $0.84(0.75-0.94)$ & $0.84(0.75-0.94)$ \\
\hline Item R: Research interests, mean (SD)* & $2.0(1.2)$ & $0.70(0.64-0.76)$ & $0.77(0.70-0.85)$ & $0.80(0.72-0.88)$ \\
\hline Item AA: Short postgraduate training, mean (SD)* & $1.9(1.1)$ & $1.46(1.33-1.60)$ & $1.21(1.08-1.35)$ & $1.11(0.99-1.25)$ \\
\hline
\end{tabular}


Not all regions of Canada were surveyed in this study; therefore, it was not fully representative of the career choices of all Canadian students. Lack of representation from the Maritimes and, particularly, from Quebec, given its unique structure of human resources in health care, may have resulted in important associations being missed. Still, students in our study chose their careers in the same proportions as all students nationally, showing the generalizability of our cohort findings. In addition, given the nature and structure of primary care in Canada and the role of family

Table 5: Multivariable logistic regression analysis of factors found to be significantly associated with switching career choice toward family medicine at exit from medical school from another career choice on entry into medical school

\begin{tabular}{|c|c|c|c|}
\hline Variable & $\begin{array}{l}\text { Students who } \\
\text { switched career } \\
\text { choice to family } \\
\text { medicine }\end{array}$ & $\begin{array}{l}\text { Crude odds } \\
\text { ratio }(95 \% \mathrm{Cl})\end{array}$ & $\begin{array}{l}\text { Adjusted odds } \\
\text { ratio }(95 \% \mathrm{Cl})\end{array}$ \\
\hline \multicolumn{4}{|l|}{$\begin{array}{l}\text { Family medicine one of top three entry } \\
\text { career choices, no. }(\%)\end{array}$} \\
\hline No & $70(12.0)$ & $1.0 \dagger$ & $1.0+$ \\
\hline Yes & $161(29.5)$ & $3.07(2.25-4.18)$ & $2.22(1.57-3.13)$ \\
\hline \multicolumn{4}{|l|}{ Relationship status, no. (\%) } \\
\hline Single & $146(17.6)$ & $1.0 \dagger$ & $1.0+$ \\
\hline Engaged or long-term & $85(28.7)$ & $1.89(1.39-2.57)$ & $1.70(1.19-2.41)$ \\
\hline \multicolumn{4}{|l|}{ Volunteer in developing nation, no. (\%) } \\
\hline No & $168(18.4)$ & $1.0 \dagger$ & $1.0+$ \\
\hline Yes & $63(29.6)$ & $1.87(1.33-2.62)$ & $1.69(1.16-2.45)$ \\
\hline Factor 5: Varied scope of practice, mean $(S D)^{*}$ & $3.4(1.0)$ & $1.35(1.17-1.55)$ & $1.25(1.06-1.46)$ \\
\hline $\begin{array}{l}\text { Item P: Prefer medical to social problems, } \\
\text { mean (SD)* }\end{array}$ & $2.4(1.3)$ & $0.78(0.70-0.86)$ & $0.86(0.75-0.98)$ \\
\hline Item R: Research interests, mean (SD)* & $2.2(1.3)$ & $0.79(0.71-0.88)$ & $0.84(0.74-0.95)$ \\
\hline $\begin{array}{l}\text { Item AA: Short postgraduate training, } \\
\text { mean (SD)* }\end{array}$ & $1.8(1.0)$ & $1.30(1.13-1.50)$ & $1.21(1.02-1.43)$ \\
\hline \multicolumn{4}{|c|}{$\begin{array}{l}\text { Note: } \mathrm{Cl}=\text { confidence interval, } \mathrm{SD}=\text { standard deviation. } \\
\text { *For continuous variables, each unit increase (i.e., year of age or unit on a Likert scale) is associated with the stated increase in } \\
\text { the odds ratio. } \\
\text { tReference category. }\end{array}$} \\
\hline
\end{tabular}

Table 6: Multivariable logistic regression analysis of factors associated with switching career choice from family medicine on entry into medical school to another career choice at exit from medical school

\begin{tabular}{|c|c|c|c|}
\hline Factor & $\begin{array}{l}\text { Students who switched career } \\
\text { choice from family medicine }\end{array}$ & $\begin{array}{l}\text { Crude odds ratio } \\
\qquad(95 \% \mathrm{Cl})\end{array}$ & $\begin{array}{l}\text { Adjusted odds ratio } \\
\qquad(95 \% \mathrm{Cl})\end{array}$ \\
\hline Age, yr, mean (SD)* & $24.1(3.2)$ & $0.91(0.86-0.96)$ & $0.92(0.86-0.98)$ \\
\hline \multicolumn{4}{|c|}{$\begin{array}{l}\text { Size of community where } \\
\text { schooling completed, no. (\%) }\end{array}$} \\
\hline$\geq 50000$ & $128(44.1)$ & $1.0 \dagger$ & $1.0 \dagger$ \\
\hline$<50000$ & 37 (29.6) & $0.53(0.34-0.83)$ & $0.46(0.23-0.92)$ \\
\hline \multicolumn{4}{|l|}{$\begin{array}{l}\text { Relative or friend in } \\
\text { medicine, no. }(\%)\end{array}$} \\
\hline No & 95 (35.7) & $1.0 \dagger$ & $1.0 t$ \\
\hline Yes & $70(47.0)$ & $1.60(1.06-2.40)$ & $1.62(1.03-2.55)$ \\
\hline $\begin{array}{l}\text { Item R: Research interests, } \\
\text { mean (SD)* }\end{array}$ & $1.9(1.2)$ & $1.23(1.02-1.47)$ & $1.24(1.01-1.51)$ \\
\hline \multicolumn{4}{|c|}{$\begin{array}{l}\text { Note: } \mathrm{Cl}=\text { confidence interval, } \mathrm{SD}=\text { standard deviation. } \\
{ }^{*} \text { For continuous variables, each unit increase (i.e., year of age or unit on a Likert scale) is associated with the stated increase in } \\
\text { the odds ratio. } \\
\text { tReference category. }\end{array}$} \\
\hline
\end{tabular}


physicians, the findings may not be directly applicable to other countries. However, given the rapid globalization of all aspects of society, including medicine, our findings (which had a high predictive value and were difficult to manipulate by applicants) provide a window into the student attitudes and demographics at medical school entry that are associated with an ultimate career choice in family medicine. Although student attitudes during the first two weeks of medical school may differ from attitudes at the time of application to medical school, it would be expected that many of the variables in this model would be unchanged and could be tested at the time of application.

\section{Conclusion}

Our study looked at the variables associated with the choice of a career in family medicine at exit from medical school. We can infer from our results that these variables, which we assessed at the second week of medical school, would be similarly predictive if assessed at the time of admissions interviews; but we do not know this, so it would be important to study this similarity directly. We would encourage schools with an interest in increasing the proportion of students choosing a career in family medicine to integrate some or all of the variables identified in our study into their student selection processes.

\section{References}

1. Chan B. From perceived surplus to perceived shortage: What happened to Canada's physician workforce in the 1990s? Ottawa (ON): Canadian Institute for Health Information; 2002. Available: http://secure.cihi.ca/cihiweb/products/chanjun02.pdf (accessed 2010 Apr. 20).

2. Cooper RA. Weighing the evidence for expanding physician supply. Ann Intern Med 2004;141:705-14.

3. Jeon S, Hurley J. The relationship between physician hours of work, service volume and service intensity. Can Public Policy 2007;33:S17-S30

4. Watson DE, Slade S, Buske L, et al. Intergenerational differences in workloads among primary care physicians: a ten-year, population-based study. Health Aff (Millwood) 2006;25:1620-8.

5. Lambert TW, Goldacre MJ, Turner G. Career choices of United Kingdom medical graduates of 2002: questionnaire survey. Med Educ 2006;40:514-21.

6. College of Family Physicians of Canada. Family medicine in Canada - vision for the future. Mississauga $(\mathrm{ON})$ : The College 2004. Available: www.cfpc.ca/local/files/Communications/Health \%20Policy/FAMILY_MEDICINE_IN_CANADA_English.pdf (accessed 2010 Apr. 20).

7. Joyce CM, McNeil JJ, Stoelwinder JU. More doctors, but not enough: Australian medical workforce supply 2001-2012. Med J Aust 2006;184:441-6.

8. Phillips RL Jr, Starfield B. Why does a U.S. primary care physician workforce crisis matter? Am Fam Physician 2004;70:440, 442, 445-46.

9. Canadian Resident Matching Service (CaRMS). 2003 career choices of Canadian students and graduates in the first iteration. Ottawa (ON): CaRMS. Available: www.carms.ca/eng/operations R1stat_2003_e.shtml\#choices (accessed 2010 Apr. 20).

10. Shuchman M. Searching for docs on foreign shores. CMAJ 2008; 178:379-80.

11. Collier R. Doctors call for plan to curb physician shortage. CMAJ 2008; 178:384

12. Kondro W. Generational attitudes and attributes to affect physician workforce. CMAJ 2007;177:1172.
13. Senf JH, Campos-Outcalt D, Kutob R. Factors related to the choice of family medicine: a reassessment and literature review. J Am Board Fam Pract 2003;16:502-12.

14. Rabinowitz HK. The role of the medical school admission process in the production of generalist physicians. Acad Med 1999; 74:S39-44.

15. Moss PJ, Lambert TW, Goldacre MJ, et al. Reasons for considering leaving UK medicine: questionnaire study of junior doctors' comments. BMJ 2004;329:1263.

16. Watanabe M, Comeau M, Buske L. Analysis of international migration patterns affecting physician supply in Canada. Healthc Policy 2008;3:e129-e138.

17. Dill M, Salsberg E. The complexities of physician supply and demand: projections through 2025. Washington (DC): Association of American Medical Colleges Center for Workforce Studies; 2008. Available: https://services.aamc.org/publications/index.cfm ?fuseaction=Product.displayForm\&prd_id $=244 \&$ cfid $=1 \&$ cftoken =51D711C6-0D94-BE53-652602C237DD67FF (accessed 2010 Oct. 13).

18. Canadian Resident Matching Service (CaRMS). Ottawa (ON): CaRMS. Available: http://www.carms.ca/eng/index.shtml (accessed 2010 Apr. 20).

19. National Residency Matching Service (NRMP). Washington (DC). Available: www.nrmp.org (accessed 2010 Apr. 20).

20. Wright B, Scott I, Woloschuk W, et al. Career choice of new medical students at three Canadian universities: family medicine versus specialty medicine. CMAJ 2004;170:1920-4.

21. Canadian Post-MD Education Registry (CAPER). Ottawa (ON): CAPER. Available: www.caper.ca (accessed 2010 Apr. 20).

22. Kassebaum DG, Szenas PL, Schuchert MK. Determinants of the generalist career intentions of 1995 graduating medical students. Acad Med 1996;71:198-209.

23. Bland CJ, Meurer LN, Maldonado G. Determinants of primary care specialty choice: a non-statistical meta-analysis of the literature. Acad Med 1995;70:620-41.

24. Babbott D, Baldwin D, Jolly P, et al. The stability of early specialty preferences among U.S. medical school graduates in 1983 JAMA 1988;259:1970-5.

25. Compton MT, Frank E, Elon L, et al. Changes in U.S. medical students' specialty interests over the course of medical school. J Gen Intern Med 2008;23:1095-100.

26. Grudzen CR, Legome E. Loss of international medical experiences: knowledge, attitudes and skills at risk. BMC Med Educ 2007;7:47.

27. Fryer GE Jr, Stine C, Vojir C, et al. Predictors and profiles of rural versus urban family practice. Fam Med 1997;29:115-8.

28. Carter RG. The relation between personal characteristics of physicians and practice location in Manitoba. CMAJ 1987; 136:366-8.

29. Schieberl JL, Covell RM, Berry C, et al. Factors associated with choosing a primary care career. West J Med 1996;164:492-6.

30. Schafer S, Shore W, French L, et al. Rejecting family practice: why medical students switch to other specialties. Fam Med 2000; 32:320-5.

31. Lawson SR, Hoban JD, Mazmanian PE. Understanding primary care residency choices: a test of selected variables in the BlandMeurer model. Acad Med 2004;79:S36-9.

Affiliations: From the Department of Family Practice (Scott, Gowans), University of British Columbia, Vancouver, BC; the Department of Family Medicine (Wright), University of Calgary, Calgary, Alta.; the Department of Family Medicine (Brenneis), University of Alberta, Edmonton, Alta.; and the Canadian Resident Matching Service (Banner, Boone), Ottawa, Ont.

Contributors: Ian Scott, Bruce Wright, Fraser Brenneis and Margot Gowans conceived the design of the study. Ian Scott, Bruce Wright, Fraser Brenneis, Sandra Banner and Jim Boone acquired the data for this study. Margot Gowans carried out the bulk of the statistical analysis and interpretation of the data. Ian Scott drafted the manuscript. All of the authors critically revised the manuscript for important intellectual content and approved the final version submitted for publication.

Funding: Funding for this study was provided by the Council of Ontario Universities.

Acknowledgements: The authors thank Janusz Kaczorowski, who provided statistical advice, and Steve Slade at the Canadian Post-MD Education Registry (CAPER), who carried out the data linkage for this study. 